\title{
Anderseniella baltica gen. nov., sp. nov., a novel marine bacterium of the Alphaproteobacteria isolated from sediment in the central Baltic Sea
}

Correspondence Ingrid Brettar inb@gbf.de

\author{
Ingrid Brettar, ${ }^{1}$ Richard Christen, ${ }^{2}$ Julia Bötel, ${ }^{1}$ Heinrich Lünsdorf ${ }^{1}$ \\ and Manfred G. Höfle ${ }^{1}$ \\ ${ }^{1} \mathrm{HZI}$-Helmholtz Center for Infection Research, Department of Vaccinology, Inhoffenstrasse 7, \\ D-38124 Braunschweig, Germany \\ ${ }^{2}$ CNRS \& Université de Nice Sophia Antipolis, UMR 6543, Centre de Biochimie, Parc Valrose, \\ F06108 Nice cedex 2, France
}

\begin{abstract}
A bacterial isolate from the Baltic Sea, designated strain $B A 141^{\top}$, was characterized for its physiological and biochemical features, fatty acid profile, pigment spectrum, DNA $\mathrm{G}+\mathrm{C}$ content and phylogenetic position based on comparative 16S rRNA gene sequence analysis. The strain was isolated from the surface of sediment in a deep basin of the central Baltic Sea. Phylogenetic analysis of the 16S rRNA gene sequence revealed a clear affiliation with the Alphaproteobacteria, and showed that the closest phylogenetic relationship was with the genus Rhodobium. The $\mathrm{G}+\mathrm{C}$ content of the DNA was $61.2 \mathrm{~mol} \%$. Cells of strain $\mathrm{BA} 141^{\top}$ were red-pigmented, Gram-negative, pleomorphic to rod-shaped, non-motile and catalase- and oxidase-positive. Growth was observed at salinities of $0.8-6 \%$, with optimum growth at $1.5-3 \%$. The temperature range for growth was $10-37{ }^{\circ} \mathrm{C}$, with optimum growth at $25-30{ }^{\circ} \mathrm{C}$. The fatty acids were dominated by unsaturated fatty acids (>86\%); the number of fatty acids detected was very low, with $18: 1 \omega 7 c(73 \%)$ as the predominant fatty acid; other major fatty acids were $19: 0$ cyclo $8 c(10 \%)$ and $16: 0$ (8\%). The pigment spectrum indicated the presence of carotenoids and unknown pigment(s) with an absorption maximum at $430 \mathrm{~nm}$, but not bacteriochlorophyll a. According to phylogenetic analysis based on the 16S rRNA gene sequence and the phenotypic features, strain $\mathrm{BA} 141^{\top}$ represents a new genus and species. The name Anderseniella baltica gen. nov., sp. nov. is proposed, with strain BA141 ${ }^{\top}\left(=\mathrm{CIP} 109499^{\top}=\mathrm{LMG}\right.$ $24028^{\top}$ ) as the type strain.
\end{abstract}

A novel bacterium was obtained from the surface layer of anoxic sediment in the central Baltic Sea (Brettar et al., 2006). Members of the Alphaproteobacteria are considered to represent a major fraction of marine bacteria (Giovannoni \& Rappé, 2000). Most of this knowledge is based on environmental sequence data rather than on cultured bacteria, because members of the Alphaproteobacteria tend to be more difficult to culture than members of the Gammaproteobacteria. Giovannoni \& Rappé (2000) concluded that this was due to their high degree of adaptation to specific environmental conditions, which

Abbreviation: PHA, polyhydroxyalkanoate.

The GenBank/EMBL/DDBJ accession numbers for the 16S rRNA and gyrB gene sequences of strain $\mathrm{BA} 141^{\top}$ are $\mathrm{AM} 712634$ and AM712635, respectively.

A table detailing results obtained using API and Biolog GN2 and tests for hydrolysis of and growth on various substrates for strain $B A 141^{\top}$ is available with the online version of this paper. renders them less amenable to cultivation on the one hand, but very successful in marine ecosystems on the other.

The novel isolate studied here was most closely related to Rhodobium orientis. Garrity et al. (2004) proposed the family 'Rhodobiaceae' comprising the genera Rhodobium and Roseospirillum. Phylogenetic studies by Lee et al. (2005) showed that there were major inconsistencies in the formation of this family and suggested that additional taxonomic studies were needed before the classification of the genus Rhodobium could be confirmed.

Strain BA $141^{\mathrm{T}}$ was isolated during a cruise onboard RV Aranda in September 1998 from the black anoxic surface of sediment (sediment top layer $0-1 \mathrm{~cm}$ depth, $5{ }^{\circ} \mathrm{C}, 11 \%$ salinity) collected at a sampling site in the central Baltic Sea, station TEILI1 $\left(59^{\circ} 26^{\prime} 07^{\prime \prime} \mathrm{N} 21^{\circ} 30^{\prime} 02^{\prime \prime} \mathrm{E}\right.$; at a depth of $165 \mathrm{~m}$ ). The sediment sample was subsampled under sterile conditions from a large sample volume. Details of the environmental conditions, sampling and isolation procedures are given elsewhere (Brettar et al., 2002; 
Brettar \& Rheinheimer, 1992; Höfle \& Brettar, 1995). The sediment sample was serially diluted with sterile seawater, spread on agar plates and incubated in the dark for 3 weeks. The medium used for isolation was half-strength ZoBell agar (Oppenheimer \& ZoBell, 1952). The strain grew well on half-strength ZoBell agar, in half-strength marine 2216 broth (Difco) and on marine agar (Difco).

The isolate was tested for a number of key characteristics using standard procedures (Gerhardt et al., 1994), such as Gram behaviour ( $\mathrm{KOH}$ string test), cell size, motility and morphology (via phase-contrast microscopy, and electron microscopy after $\mathrm{Pt} / \mathrm{C}$ shadow casting or thin sectioning) and cytochrome oxidase and catalase $\left(3 \% \mathrm{H}_{2} \mathrm{O}_{2}\right)$. Growth on $1 \%$ yeast extract, $1 \%$ peptone, $0.2 \% \beta$-hydroxybutyrate and MacConkey agar was tested. In addition, the production of indole, nitrate reduction and hydrolysis of aesculin, casein, tyrosine, starch, gelatin and DNA were tested. Chitinase, cellulase and pectinase activities were tested as described by Atlas (1993).

For electron microscopy, samples from a liquid culture of strain $\mathrm{BA} 141^{\mathrm{T}}$ were adsorbed onto carbon-Formvar foil, washed with water, blotted and air-dried. They were shadow-casted at 15 deg elevation with platinum-carbon and analysed using an energy-filter transmission electron microscope (CEM902; Zeiss), as described by Golyshina et al. (2000). Embedding and thin-sectioning were performed as described by Yakimov et al. (1998).

In addition, strain $\mathrm{BA} 141^{\mathrm{T}}$ was characterized by using the whole test spectra of the identification systems API $50 \mathrm{CH}$, API 20NE, API ZYM (bioMérieux) and Biolog GN2 at $28{ }^{\circ} \mathrm{C}$. Growth at different temperatures was assessed at 4, $10,20,25,30,37$ and $42{ }^{\circ} \mathrm{C}$. Growth at different salinities was tested at $0,0.8,1.0,1.5,3,6$ and $10 \%$, with salt being added as $\mathrm{NaCl}$ or Biomaris sea salt. Growth at different $\mathrm{pH}$ was tested at $\mathrm{pH}$ 5.7, 7 and $9.7(\mathrm{pH}$ adjusted using bicarbonate buffer or $\mathrm{HCl}$, with growth assessed based on the occurrence of visible colonies on agar). For these tests we used half-strength marine broth or agar (Difco 2216), except for the salinity test for which half-strength salt-free ZoBell medium was supplemented with the respective amount of $\mathrm{NaCl}$ or Biomaris sea salt.

Pigment analysis was performed according to Hiraishi et al. $(1995,2000)$, i.e. the same procedure as used for analysis of the genus Rhodobium (Hiraishi et al., 1995). Briefly, after growth in half-strength marine broth, cells were washed three times in PBS and either (i) resuspended in $50 \mathrm{mM}$ phosphate buffer $(\mathrm{pH} \mathrm{7.0)}$, sonicated for $3 \mathrm{~min}$ and centrifuged to remove cell debris or (ii) extracted in icecold acetone/methanol solution $(7: 2, \mathrm{v} / \mathrm{v})$ in the dark for $12 \mathrm{~h}$. Absorption spectra of the resultant cell extracts were recorded spectrophotometrically from 300-900 nm.

Genomic DNA was prepared from individual colonies as described by Moore et al. (1996). 16S rRNA genes were amplified by PCR according to Mullis \& Faloona (1987). The gyrase B ( gyrB) gene sequence was amplified by PCR as described by Yamamoto \& Harayama (1995). The PCRproducts were sequenced directly as described by Moore et al. (1999).

For phylogenetic analysis based on the 16S rRNA gene sequence, the most similar sequences were identified by running BLAST queries at NCBI (nr database), with the filter option set to false. These sequences were included and aligned within a local database of 289000 previously aligned and analysed bacterial $16 \mathrm{~S}$ rRNA gene sequences. In a first analysis, new sequences were carefully aligned (manual adjustments) and analysed by phylogeny (BIONJ, as detailed below). This was done to demonstrate that the novel strain was not related to any previously described genus. Among the 117 related sequences, 22 sequences of known type strains were selected and analysed further using three phylogenetic methods (BIONJ, maximumlikelihood and maximum-parsimony). For the neighbourjoining analysis, distance matrices were calculated using the Kimura two-parameter correction, BIONJ was used according to Gascuel (1997), and maximum-likelihood and maximumparsimony (using the Global option) were from PHYLIP (Felsenstein, 1993). Bootstrap analyses were performed using BIONJ based on 1000 replications. The phylogenetic trees were drawn using TreeDyn (Chevenet et al., 2006). The results of the final phylogenetic analysis are shown in Fig. 1. Phylogenetic analysis based on gyrB gene sequences was not successful due to a lack of available gyrB gene sequences in the phylogenetic neighbourhood of strain $\mathrm{BA} 141^{\mathrm{T}}$. Therefore, only the GenBank/EMBL/DDBJ number for the gyrB gene sequence of strain $\mathrm{BA} 141^{\mathrm{T}}$ is provided.

The DNA G $+\mathrm{C}$ content $(\mathrm{mol} \%)$ of strain $\mathrm{BA} 141^{\mathrm{T}}$ was determined using HPLC analysis of hydrolysed DNA according to Tamaoka \& Komagata (1984) and Mesbah et al. (1989).

For analysis of the cellular fatty acid profile, strain BA141 ${ }^{\mathrm{T}}$ was grown on half-strength marine agar 2216 for $24 \mathrm{~h}$ at $28{ }^{\circ} \mathrm{C}$. Fatty acid methyl esters were obtained from washed cells by saponification, methylation and extraction. Gas chromatography analysis was controlled by MIS software (Microbial ID) and the peaks were automatically integrated and identified using the microbial identification software package (Sasser, 1990).

Cells of strain $\mathrm{BA}_{141^{\mathrm{T}}}$ were Gram-negative, non-motile, pleomorphic rods, $1-5 \mu \mathrm{m}$ in length and $0.5-1 \mu \mathrm{m}$ in width (Fig. $2 \mathrm{a}-\mathrm{c}$ ). On marine agar, strain $\mathrm{BA} 141^{\mathrm{T}}$ formed small dark-red-pigmented opaque colonies. When grown in halfstrength marine broth, the culture had a light to intense orange-red colour. Cells harvested from liquid culture were bright-red in colour. Strain BA141 ${ }^{\mathrm{T}}$ was slow-growing, with irregular lag phases after inoculation. To obtain visible growth on agar or in liquid culture, an incubation time of about 1 week at room temperature was required, with 2-4 weeks incubation for a densely grown culture.

Electron microscopy of shadow-casted cells showed that the cells had irregular shapes, often with branching (Fig. 2a 


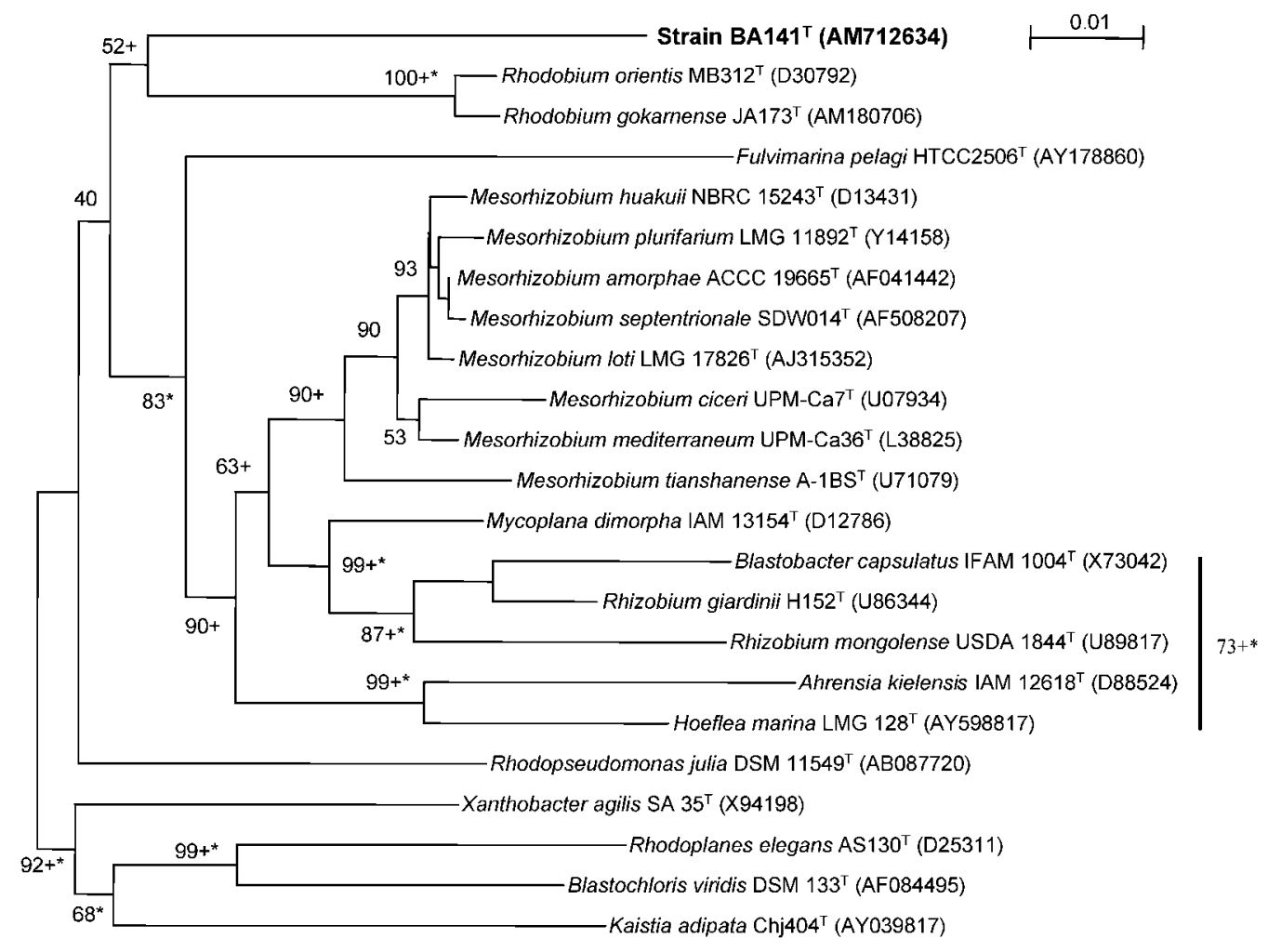

Fig. 1. Unrooted phylogenetic tree resulting from the analysis of nearly complete $16 \mathrm{~S}$ rRNA gene sequences of the most related type strains. The topology shown was obtained using neighbour-joining based on 1000 bootstrap replications. Bootstrap percentages are indicated as well as branches that were also found by using maximum-parsimony (indicated by a plus sign) and maximum-likelihood $(P<0.01)$ (indicated by an asterisk) and therefore that define robust clusters. Bar, 0.01 substitutions per nucleotide position.

and c-e). In liquid culture, cells formed star-like cell aggregates. Ultrastructural analysis using electron microscopy revealed the presence of polyhydroxyalkanoate (PHA) deposits. Enlargement of the cells was often observed in the vicinity of the PHA deposits. Neither budding cells, flagella nor intracytoplasmic membranes were observed, as was the case for Rhodobium orientis (Hiraishi et al., 1995).

All details on the physiological and biochemical traits are summarized in the species description and in Supplementary Table S1 (available in IJSEM Online). In general, strain $\mathrm{BA} 141^{\mathrm{T}}$ showed no substrate use in the API $50 \mathrm{CH}$ and API 20NE test systems and a rather limited and mostly weak substrate use was recorded using the API ZYM test system. Substrates used in the Biolog GN2 test systems were mostly organic acids plus L-arabinose, alaninamide and glycerol. As a general rule, phenotypic features were rated as positive when a weak or more pronounced signal was obtained (for details see Supplementary Table S1).

The pigment spectrum of the sonicated cell extract showed a major peak at $430 \mathrm{~nm}$, with shoulder peaks around 470 , 500 and $530 \mathrm{~nm}$ (Fig. 3). In addition, a minor peak occurred at $365 \mathrm{~nm}$. No peaks above $600 \mathrm{~nm}$ were observed, indicating that strain $\mathrm{BA} 141^{\mathrm{T}}$ did not contain bacteriochlorophyll $a$. The large peak at $430 \mathrm{~nm}$ was not identified; the shoulder peaks on the large peak between 470 and $530 \mathrm{~nm}$ were considered to indicate the presence of carotenoids. The pigment spectrum was very different from that of Rhodobium orientis, which showed pronounced peaks for bacteriochlorophyll $a$ at 800 and $870 \mathrm{~nm}$, but no peak at $430 \mathrm{~nm}$ (Hiraishi et al., 1995). In the acetone/methanol extract of strain $\mathrm{BA} 141^{\mathrm{T}}$ a broad peak from 450 to $550 \mathrm{~nm}$ was observed, supporting the presence of carotenoids.

In terms of phenotypic features, strain $\mathrm{BA} 141^{\mathrm{T}}$ differed with respect to many of those of the phylogenetically closest related species Rhodobium orientis (Table 1). Differences were observed in the presence of flagella, formation of budding cells, presence of bacteriochlorophyll $a$ and intracytoplasmic membranes, and loss of pigmentation in oxic cultures. In terms of physiological features, they differed regarding denitrification, and the use of sugars and alcohols (Hiraishi et al., 1995). The two species were able to use a broad spectrum of organic acids.

Phylogenetic analysis based on 16S rRNA gene sequences revealed that strain $\mathrm{BA} 141^{\mathrm{T}}$ did not form a robust clade 

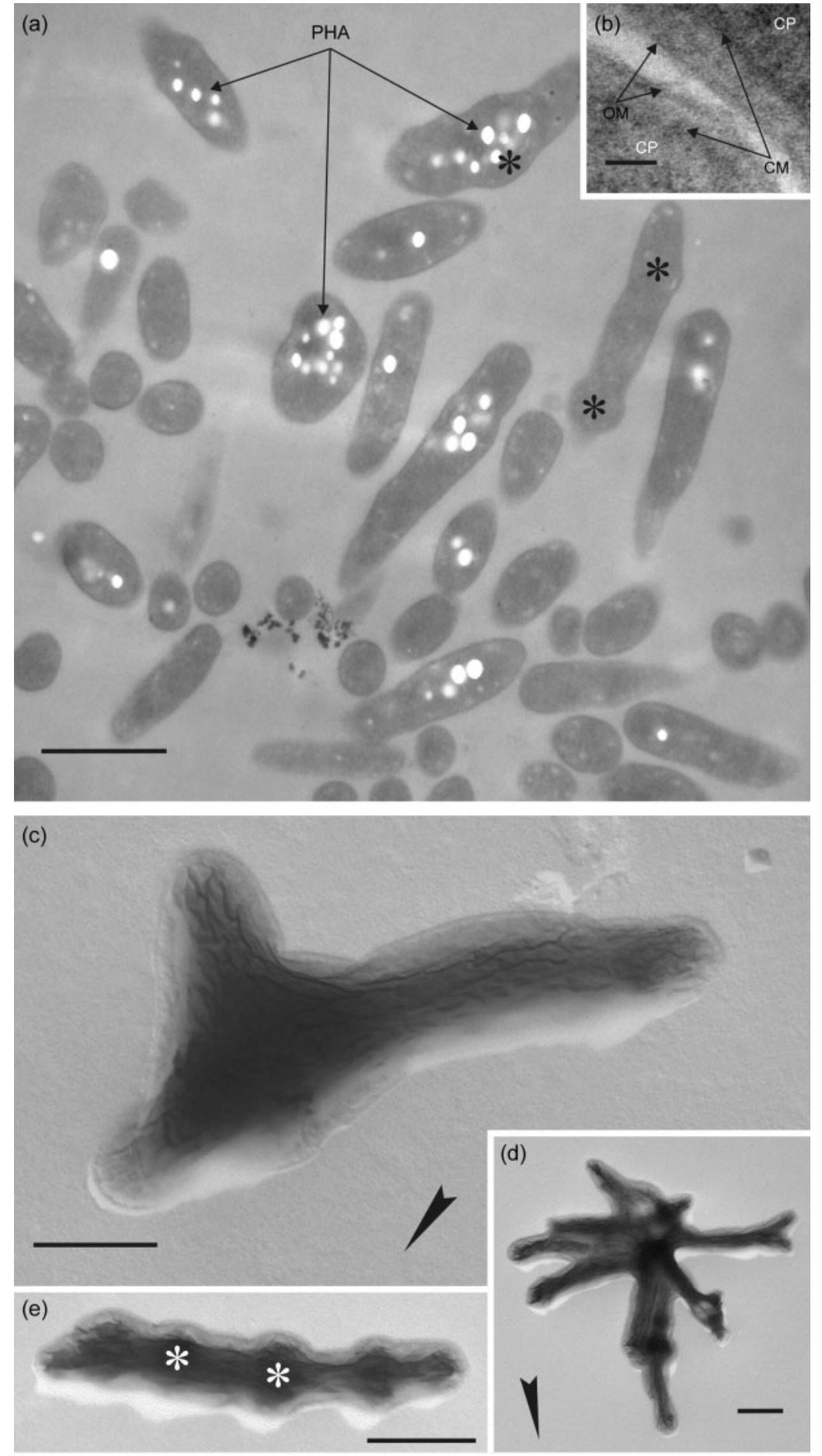

Fig. 2. Ultrastructural analysis of cells of strain BA $141^{\top}$ grown in half-strength marine broth (21 ${ }^{\circ} \mathrm{C}$, daylight). (a) Survey view of ultrathinsectioned bacteria showing the overall features and often irregular contours of the cells. These cytoplasmic dilatations (indicated by asterisks) are often related to the presence of PHA deposits. (b) Detail of a bacterial cell, revealing the presence of an outer membrane (OM), indicative of a Gram-negative type of cell wall. (CM, cytoplasmic membrane; $\mathrm{CP}$, cytoplasm). (c, d, e) Overall morphologies of $\mathrm{Pt} / \mathrm{C}$ shadow-casted cells, which especially reveal the pleomorphic feature of individual cells (c, e) and star-like aggregates (d). Arrows in (c) and (d) indicate the shadowing direction. Bars, $1 \mu \mathrm{m}$ (a, d and e), $50 \mathrm{~nm}$ (b) and $500 \mathrm{~nm}$ (c). with any other previously described genus; a grouping with the genus Rhodobium was revealed by using BIONJ and maximum-parsimony, but not maximum-likelihood (Fig. 1). In addition, the bootstrap support of the neighbour-joining analysis was low (52\%; Fig. 1). This is a strong indication that strain $\mathrm{BA} 141^{\mathrm{T}}$ represents a new genus. Rhodobium orientis (GenBank no. D30792) had a 16S rRNA gene sequence similarity of $92.5 \%$ with strain $\mathrm{BA} 141^{\mathrm{T}}$. Also, with most species of the genus
Mesorhizobium, a 16S rRNA gene sequence similarity of $92 \%$ or below was observed. In comparison to $16 \mathrm{~S}$ rRNA gene sequences derived from cultured bacteria, 16S rRNA gene sequence similarities of above $93 \%$ were not observed.

The DNA G + C content of strain BA141 ${ }^{\mathrm{T}}$ was $61.2 \mathrm{~mol} \%$ (Table 1). Values for strains of the related species Rhodobium orientis ranged from 61.5 to $65.7 \%$ and are therefore within the same range as that for strain $\mathrm{BA} 141^{\mathrm{T}}$. 


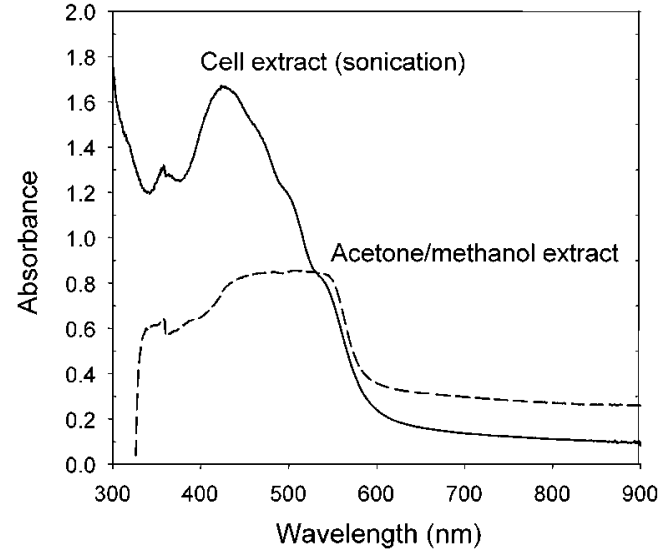

Fig. 3. Absorption spectra of cell extracts of strain $B A 141^{\top}$ obtained from sonicated (solid line) and from acetone/methanol (dashed line) extracted cells.

The fatty acid profile was dominated by unsaturated fatty acids $(>86 \%)$ and showed a low number of detected fatty acids. The fatty acid profile was composed of $14: 0(0.5 \%)$, $16: 1 \omega 11 c(1.0 \%), 16: 0 \quad(8.2 \%), 16: 0 \quad 2-\mathrm{OH} \quad(1.0 \%)$, $18: 1 \omega 9 c(1.8 \%), 18: 1 \omega 7 c(73.3 \%), 19: 0$ cyclo $\omega 8 c$ $(9.9 \%)$ and an unknown component (ECL 11.799, $4.3 \%)$. Thus the fatty acid spectrum was strongly dominated by $18: 1 \omega 7 c$. The fatty acid profile of strain $\mathrm{BA} 141^{\mathrm{T}}$ was similar to those of members of the genus
Mesorhizobium, with the closest similarity with Mesorhizobium plurifarium (Tighe et al., 2000).

Based on $16 \mathrm{~S}$ rRNA gene sequence analysis, strain BA141 ${ }^{\mathrm{T}}$ belongs to the Alphaproteobacteria, but is clearly identified as representing a new genus. Also, from a phenotypic perspective, the most closely related species and the only described representative of the genus Rhodobium at the time of writing, Rhodobium orientis, showed many features that were different from those of strain $\mathrm{BA} 141^{\mathrm{T}}$, i.e. presence of flagella, formation of budding cells, presence of bacteriochlorophyll $a$ and intracytoplasmic membranes, loss of pigmentation in oxic cultures, and many physiological features, such as denitrification, and broader use of sugars and alcohols (Hiraishi et al., 1995).

Based on the polyphasic approach used, we propose a new genus and species, Anderseniella baltica gen. nov., sp. nov., to accommodate the novel Baltic Sea isolate, with strain $\mathrm{BA} 141^{\mathrm{T}}$ as the type strain.

\section{Description of Anderseniella gen. nov.}

Anderseniella (An.der.sen.i.el'la. N.L. dim. n. Anderseniella named in honour of the late marine scientist Valérie Andersen, Observatoire Océanologique de Villefranche sur Mer, France, in recognition of her valuable work on marine ecosytems).

Cells are Gram-negative, rod-shaped to pleomorphic, and oxidase- and catalase-positive. Non-flagellated and redpigmented. Growth is heterotrophic and aerobic. Pre-

Table 1. Differential phenotypic features between strain $B A 141^{\top}$ (Anderseniella baltica sp. nov.) and Rhodobium orientis

+, Positive; -, negative. Data for Rhodobium orientis are from Hiraishi et al. (1995).

\begin{tabular}{|c|c|c|}
\hline Feature & Strain BA141 ${ }^{\mathrm{T}}$ & Rhodobium orientis \\
\hline Site of isolation & $\begin{array}{c}\text { Central Baltic Sea, basin }(165 \mathrm{~m}) \text {; } \\
\text { sediment surface }\end{array}$ & $\begin{array}{l}\text { Japan, coast, tidal pools; } \\
\text { seawater and mud }\end{array}$ \\
\hline Size $(\mu \mathrm{m})$ & $0.5-1.0 \times 1.0-5.0$ & $0.7-0.9 \times 1.0-3.2$ \\
\hline Motility & - & $+($ several flagella $)$ \\
\hline Culture colour at aerobic growth & Orange-red & Colourless \\
\hline Bacteriochlorophyll $a$ & - & + \\
\hline Intracytoplasmic membranes & - & + \\
\hline Budding cells & - & + \\
\hline DNA G $+C$ content $(\mathrm{mol} \%)$ & 61.2 & $61.5-65.7$ \\
\hline Denitrification & - & + \\
\hline \multicolumn{3}{|l|}{ Utilization of: } \\
\hline Formate & + & - \\
\hline Valerate & - & + \\
\hline Succinate & - & + \\
\hline L-Arabinose & + & - \\
\hline Fructose & - & + \\
\hline Glucose & - & + \\
\hline Mannitol & - & + \\
\hline Sorbitol & - & + \\
\hline Glycerol & + & - \\
\hline
\end{tabular}


dominant fatty acid is $18: 1 \omega 7 c$. Other major fatty acids are 16:0 and 19:0 cyclo $\omega 8$ c. Cells contain carotenoids but not bacteriochlorophyll $a$. Cells contain PHA. Member of the Alphaproteobacteria. The type species is Anderseniella baltica.

\section{Description of Anderseniella baltica sp. nov.}

Anderseniella baltica (bal'ti.ca. N.L. fem. adj. baltica from the Baltic Sea, referring to the source of the type strain).

Exhibits the following properties in addition to those given in the species description. Colonies are small, opaque, circular, smooth, convex and entire. Forms dark-red colonies and light to intense orange-red liquid cultures (>1 week, $25{ }^{\circ} \mathrm{C}$, half-strength marine broth). Cells are partially branching (width $0.5-1.0 \mu \mathrm{m}$, length $1.0-5.0 \mu \mathrm{m}$ ). Cells form star-like aggregates in liquid culture. Grows at oxic to low oxic conditions. Does not reduce nitrate to nitrite. Temperature for growth ranges from 10 to $37^{\circ} \mathrm{C}$, with optimum growth at $25-30{ }^{\circ} \mathrm{C}$. Salinity range for growth is from 0.8 to $6 \%$ of final concentration of artificial sea salt; addition of $\mathrm{NaCl}$ alone is not sufficient for growth. Grows at pH 7-7.5; no growth occurs at $\mathrm{pH} 5.7$ or 9.7. Grows on $1 \%$ yeast extract and $1 \%$ peptone, but not on aesculin, casein or $\beta$-hydroxybutyrate. Does not hydrolyse starch, gelatin, tyrosine, DNA, cellulose, chitin or pectin. Does not produce indole. Does not grow on MacConkey agar. Acid production is not observed using the API $50 \mathrm{CH}$ test system. All API 20NE tests are negative. In the API ZYM test system, alkaline phosphatase, esterases (C4 and C8) and leucine arylamidase are positive; all other tests are negative. In the Biolog GN2 system, positive results are obtained for L-arabinose, glycerol, alaninamide and the organic acids succinic acid monomethyl ester, acetic acid, formic acid, $\alpha$-hydroxybutyric acid, $\beta$-hydroxybutyric acid, $\alpha$-ketobutyric acid, DL-lactic acid, succinamic acid and urocanic acid; all other tests are negative. In general, the use of organic acids is better than for other substrates. All unmentioned tests of the API and Biolog GN2 test systems are negative. A detailed overview of all positive and negative test results for the biochemical tests is given in Supplementary Table S1 (in IJSEM Online). The DNA $\mathrm{G}+\mathrm{C}$ content of the type strain is $61.2 \mathrm{~mol} \%$.

The type strain, BA141 ${ }^{\mathrm{T}}\left(=\mathrm{CIP} 109499^{\mathrm{T}}=\mathrm{LMG} 24028^{\mathrm{T}}\right)$, was isolated from the surface layer of anoxic sediment in the central Baltic Sea.

\section{Acknowledgements}

The support of the scientific and technical crew of RV Aranda in September 1998 is greatly acknowledged. Special thanks are given to H. Kuosa and J. Kupparinen for support with sampling and the cruise. The analytical services of the DSMZ (Deutsche Sammlung für Mikroorganismen und Zellkulturen, Braunschweig, Germany) are greatly acknowledged. Many thanks to S. Verbarg, R. M. Kroppenstedt and P. Schumann and their staff. Many thanks for the excellent support by A. Frühling. I. Kristen is gratefully acknowledged for skilful assistance of sample preparation for electron microscopy. We greatly acknowledge the support of J. Euzéby regarding the name of the strain, and the valuable suggestions of unknown reviewers. This work was supported by funds from the European Commission for the projects 'Marine Bacterial Genes and Isolates as Sources for Novel Biotechnological Products' (MARGENES, MAS3-CT97-0125, MASTIII programme) and AQUA-CHIP (QLK4-2000-00764). The authors are solely responsible for the content of this publication. It does not represent the opinion of the European Commission. The European Commission is not responsible for any use that might be made of data appearing herein.

\section{References}

Atlas, R. M. (1993). Handbook of Microbiological Media. Edited by L. C. Parks. Boca Raton, FL: CRC Press.

Brettar, I. \& Rheinheimer, G. (1992). Influence of carbon availability on denitrification in the water column of the central Baltic. Limnol Oceanogr 37, 1146-1163.

Brettar, I., Christen, R. \& Höfle, M. G. (2002). Rheinheimera baltica gen. nov., sp. nov., a blue coloured bacterium isolated from the central Baltic Sea. Int J Syst Evol Microbiol 52, 1851-1857.

Brettar, I., Labrenz, M., Flavier, S., Bötel, J., Kuosa, H., Christen, R. \& Höfle, M. G. (2006). Identification of a Thiomicrospira denitrificanslike epsilonproteobacterium as a catalyst for autotrophic denitrification in the central Baltic Sea. Appl Environ Microbiol 72, 1364-1372.

Chevenet, F., Brun, C., Banuls, A. L., Jacq, B. \& Christen, R. (2006). TreeDyn: towards dynamic graphics and annotations for analyses of trees. BMC Bioinformatics 7, 439.

Felsenstein, J. (1993). PHYLIP (phylogeny inference package), version 3.5c. Distributed by the author. Department of Genome Sciences, University of Washington, Seattle, USA.

Garrity, G. M., Bell, J. A. \& Liburn, T. G. (2004). Taxonomic Outline of the Prokaryotes. Bergey's Manual of Systematic Bacteriology, 2nd edn, release 5.0. New York: Springer. DOI: 10.1007/bergeysoutline

Gascuel, O. (1997). BIONJ: an improved version of the NJ algorithm based on a simple model of sequence data. Mol Biol Evol 14, 685-695.

Gerhardt, P., Murray, R. G. E., Wood, W. A. \& Krieg, N. R. (1994). Methods for General and Molecular Bacteriology. Washington DC: American Society for Microbiology.

Giovannoni, S. J. \& Rappé, M. (2000). Evolution, diversity, and molecular ecology of marine procaryotes. In Microbial Ecology of the Oceans, pp. 47-84. Edited by D. L. Kirchman. New York: Wiley.

Golyshina, O. V., Pivovarova, T. A., Karavaiko, G. I., Kondrat'eva, T. F., Moore, E. R. B., Abraham, W.-R., Lünsdorf, H., Timmis, K. N., Yakimov, M. M. \& Golyshin, P. N. (2000). Ferroplasma acidophilum gen. nov., sp. nov., an acidophilic, autotrophic, ferrous-ironoxidizing, cell-wall-lacking, mesophilic member of the Ferroplasmaceae fam. nov., comprising a distinct lineage of the Archaea. Int $J$ Syst Evol Microbiol 50, 997-1006.

Hiraishi, A., Urata, K. \& Satoh, T. (1995). A new genus of marine budding phototrophic bacteria, Rhodobium gen. nov., which includes Rhodobium orientis sp. nov. and Rhodobium marinum comb. nov. Int J Syst Bacteriol 45, 226-234.

Hiraishi, A., Matsuzawa, Y., Kanbe, T. \& Wakao, N. (2000). Acidisphaera rubrifaciens gen. nov., sp. nov., an aerobic bacteriochlorophyll-containing bacterium isolated from acidic environments. Int J Syst Evol Microbiol 50, 1539-1546.

Höfle, M. G. \& Brettar, I. (1995). Taxonomic diversity and metabolic activity of microbial communities in the water column of the central Baltic Sea. Limnol Oceanogr 40, 868-874. 
Lee, K.-B., Liu, C.-T., Anzai, Y., Kim, H., Aono, T. \& Oyaizu, H. (2005). The hierarchical system of the 'Alphaproteobacteria': description of Hyphomonadaceae fam. nov., Xanthobacteraceae fam. nov. and Erythrobacteraceae fam. nov. Int J Syst Evol Microbiol 55, 1907-1919.

Mesbah, M., Premachandran, U. \& Whitman, W. B. (1989). Precise measurement of the $\mathrm{G}+\mathrm{C}$ content of deoxyribonucleic acid by highperformance liquid chromatography. Int J Syst Bacteriol 39, 159-167.

Moore, E. R. B., Mau, M., Arnscheidt, A., Böttger, E. C., Hutson, R. A., Collins, M. D., Van De Peer, Y., De Wachter, R. \& Timmis, K. N. (1996). The determination and comparison of the 16S rRNA gene sequences of species of the genus Pseudomonas (sensu stricto) and estimation of the natural intrageneric relationships. Syst Appl Microbiol 19, 476-492.

Moore, E. R. B., Arnscheidt, A., Krüger, A., Strömpl, C. \& Mau, M. (1999). Simplified protocols for the preparation of genomic DNA from bacterial cultures. In Molecular Microbial Ecology Manual 1.6.1, pp. 1-15. Edited by A. D. L. Akkermans, J. D. van Elsas \& F. J. de Bruijn. Dordrecht: Kluwer.

Mullis, K. B. \& Faloona, E. (1987). Specific synthesis of DNA in vitro via a polymerase-catalyzed chain reaction. Methods Enzymol 155, 335-350.
Oppenheimer, C. H. \& ZoBell, C. E. (1952). The growth and viability of sixty-three species of marine bacteria as influenced by hydrostatic pressure. J Mar Res 11, 10-18.

Sasser, M. (1990). Identification of bacteria by gas chromatography of cellular fatty acids, MIDI Technical Note 101. Newark, DE: MIDI Inc.

Tamaoka, J. \& Komagata, K. (1984). Determination of DNA base composition by reversed-phase high-performance liquid chromatography. FEMS Microbiol Lett 25, 125-128.

Tighe, S. W., de Lajudie, P., Dipietro, K., Lindstrom, K., Nick, G. \& Jarvis, B. D. (2000). Analysis of cellular fatty acids and phenotypic relationships of Agrobacterium, Bradyrhizobium, Mesorhizobium, Rhizobium and Sinorhizobium species using the Sherlock Microbial Identification System. Int J Syst Evol Microbiol 50, 787-801.

Yakimov, M. M., Golyshin, P. N., Lang, S., Moore, E. R. B., Abraham, W.-R., Lünsdorf, H. \& Timmis, K. N. (1998). Alcanivorax borkumensis gen. nov., sp. nov., a new hydrocarbon-degrading and surfactantproducing marine bacterium. Int J Syst Bacteriol 48, 339-348.

Yamamoto, S. \& Harayama, S. (1995). PCR amplification and direct sequencing of $\operatorname{gyr} B$ genes with universal primers and their application to the detection and taxonomic analysis of Pseudomonas putida strains. Appl Environ Microbiol 61, 1104-1109. 